\title{
Biosorption of Iron from Ground Water by Biomasses of Yeast (Saccharomyces cerevisiae )
}

\author{
${ }^{1}$ Naziha M. Hassanein, ${ }^{1}$ M.F. Ahmed, ${ }^{2}$ A.H. Mostafa, \\ ${ }^{2}$ Maha M. Elshafei , ${ }^{2}$ Marwy A. Ahmed and ${ }^{3}$ Hend M. Khater \\ ${ }^{1}$ Microbiology department, Faculty of Science, Ain shams \\ University, ${ }^{2}$ National Reaserch center and ${ }^{3}$ National Center \\ for Research on Housing and Building
}

\begin{abstract}
7 LEVEN $S$. cerevisiae strains alive and dead forms were W screened for biosorption and bioaccumulation of iron from prepared aqueous solution. S. cerevisiae strains F-707 in alive form was found to be excellent $\mathrm{Fe}^{+2}$ biosorbent that biosorbed $21.9 \mathrm{mg}$ $\mathrm{Fe}^{+2} / \mathrm{g}$ yeast biomass. Optimization of cultural conditions revealed that optimum concentration of $\mathrm{Fe}^{+2}$ was $5.6 \mathrm{mg} \mathrm{Fe} \mathrm{e}^{+2} / 1$ after $20 \mathrm{~min}$ at $\mathrm{pH} 7$, agitation rate, $150 \mathrm{rpm}$ and yeast biomass concentration $0.1 \mathrm{~g}$ $/ 1$ at $30^{\circ} \mathrm{C}$ for maximum $\mathrm{Fe}^{+2}$ biosorption by S.cerevisiae F-707 in alive form
\end{abstract}

Keywords: Biosorption, Iron,Ground water, Saccharomyces cerevisiae.

In Egypt wells have been used since 3000 BC. (Sharma., 2001). Iron is mainly present in ground water in two forms: either soluble ferrous iron or insoluble ferric iron. Water containing ferrous iron is clear and colorless because iron is completely dissolved. When the water is exposed to air, it turns cloudy and a reddish brown substance begins to form. This sediment is the oxidized hydroxide iron that is not dissolved in water (Das et al., 2007). Conventional methods for removing metal ions from aqueous solution such as chemical precipitation, ion exchange, electrochemical treatment, membrane technologies and adsorption on activated carbon cannot be used at large scale. This is either due to their infectiveness with low metal ion concentration or their extreme expensiveness (Wang and Chen, 2006). Biosorption and bioaccumulation belong to the group of biological methods suitable for heavy metals removal from wastewater. Big advantages of these methods are the low operating cost, minimization of the volume of chemical and/or biological sludge to be disposed of and high efficiency in detoxifying very dilute effluents (Kadukova and Vircikova, 2005). Biosorption is a rapid, metabolically passive process. The biomass usually sequesters metal through surface bonding only. Bioaccumulation is an intracellular accumulation of sorbate (Chojnacka, 2010). Bioaccumulation is a slow, metabolically active process. In this process the metals are concentrated through a combination of surface reaction, intra- and extracellular precipitation, and intra -and extracellular complexation reactions (Aksu, 1998). Ferraz et al. (2004) used brewery waste $S$. cerevisiae for removing silver and uranium from laboratoryprepared aqueous solutions. Parvathi and Nagendran (2008) used waste yeast $S$. 
cerevisiae from beer fermentation industry for the biosorption of chromium from electroplating effluent.

Wang and Chen (2006) reported that S. cerevisiae has many advantages as biosorbent in metal biosorption. Firstly $S$. cerevisiae is easy to cultivate at large scale, the yeast can be easily grown using unsophisticated fermentation techniques and inexpensive growth media. Moreover, the yield of the biomass is high. Secondly, the biomass of S. cerevisiae can be obtained from various food and beverage industries as a by-product. Thirdly, $S$. cerevisiae is generally regarded as safe. Therefore, biosorbents made from $S$. cerevisiae can be easily accepted by the public when applied practically. Fourthly, but not the last, $S$. cerevisiae is an ideal model organism to identify the mechanism of biosorption in metal ions removal.

\section{Material and Methods}

\section{Yeast strains}

Eleven yeasts (Saccharomyces cerevisiae) strains were obtained from culture collection of Microbial Chemistry Dep. National Research Center, Dokki, Giza, Egypt. The yeast strains were then routinely maintained on PDA at $4^{\circ} \mathrm{C}$.

\section{Preparation of metal ions}

The stock metal ions solution was prepared by dissolving ferric chloride of analytical grade in deionized water to obtain a concentration of $1000 \mathrm{mg} / \mathrm{l}$ further dilutions were made during the course of the experiments to obtain different concentrations as desired.

Screening yeasts biomass for the biosorption of $\mathrm{Fe}^{+2}$.

Fifty $\mathrm{ml}$ double distilled water $\left(\mathrm{ddH}_{2} \mathrm{O}\right)$ was amended with $\mathrm{Fe}^{+2}$ to attain conc-entration $2.3 \mathrm{mg} \mathrm{Fe}{ }^{+2} / \mathrm{l}$, then poured in $250-\mathrm{ml}$ Erlenmeyer flasks inoculated with $0.1 \mathrm{gm}$ from different yeast strains biomass in alive and dead forms and then incubated for $180 \mathrm{~min}$. at $28^{\circ} \mathrm{C}$ in shaking incubator (200 rpm). Samples were filtered using Whatman No.1 filter paper. The concentration of iron remaining in the filtrate was analysed using Atomic adsorption (thermo scientific ice 3000 series) this experiment was repeated with chosen the most strain biosorbents with decreased time to $90 \mathrm{~min}$.

Under the above conditions samples were withdrawn at 10, 20, 30, 45, 90 and 180 min. intervals and analyzed for $\mathrm{Fe}^{+2}$.

Different concentrations of $\mathrm{Fe}^{+2}$ including 0.8, 1.6, 2.4, 3.2, 4.0, 4.8 and 5.6 $\mathrm{mg} \mathrm{Fe} / 1$ aqueous solution contained $0.1 \mathrm{~g} / 1$ S. cerevisiae F-707 biomass in alive form were incubated for $20 \mathrm{~min}$. at $28^{\circ} \mathrm{C}$ in shaking incubator $(200 \mathrm{rpm})$.

Different concentrations of S. cerevisiae F-707 biomass in alive form like $0.1,0.2,0.3$, and $0.4 \mathrm{~g} / \mathrm{l}$ aqueous solution contained $5.6 \mathrm{mg} \mathrm{Fe} \mathrm{e}^{+2} / 1$ were incubated for $20 \mathrm{~min}$. at $28^{\circ} \mathrm{C}$ in shaking incubator $(200 \mathrm{rpm})$.

Egypt. J. Bot., Vol. 55, No. 2 (2015) 
The aqueous solution contained $0.1 \mathrm{~g} / \mathrm{l}$ of $S$. cerevisiae F-707 biomass in alive form and $5.6 \mathrm{mg} \mathrm{Fe}^{+2} / 1$, was adjusted to $\mathrm{pH} 4.5,5,5.5,6,6.5,7,7.5,8,8.5$ and 9 using $0.1 \mathrm{M} \mathrm{HCl}$ or $0.1 \mathrm{M} \mathrm{NaOH}$, and left for $20 \mathrm{~min}$. at $28^{\circ} \mathrm{C}$ in shaking incubator $(200 \mathrm{rpm})$.

Different agitation rates 100, 150, 200 and $250 \mathrm{rpm}$ for $20 \mathrm{~min}$. were applied to study their effects on the $\mathrm{Fe}^{+2}$ biosorption in solution containing $5.6 \mathrm{mg} \mathrm{Fe}^{+2} / 1$ and $0.1 \mathrm{~g}$ alive $S$. cerevisiae F-707 biomass .

The temperature was maintained at $20,25,30,35$ and $40^{\circ} \mathrm{C}$ and agitation rate $150 \mathrm{rpm}$ were applied to study their effects on the iron biosorbstion in solution containing $5.6 \mathrm{mg} \mathrm{Fe}^{+2} / 1$ and $0.1 \mathrm{~g}$ alive S. cerevisiae F-707 biomass .

Yeast pelletes were examined using Scanning electron microscope (SEM) and energy dispersive X-ray spectrometer (EDX). The yeast strain 707F was grown in distilled water without $\mathrm{Fe}^{+2}$ as control and grew in distilled water with $\mathrm{Fe}^{+2}$ contains $5.6 \mathrm{mg} / \mathrm{IFe}^{+2}$. After $20 \mathrm{~min}$. incubation at $28^{\circ} \mathrm{C}$ and $150 \mathrm{rpm}$, the yeast cells separated and then washed with distilled water. The washed yeast cells were smeared over the cover slip coated with poly-L-lysin for $30 \mathrm{~min}$. in wet condition (Srivastava and Thakur, 2006).The specimen washed with buffer, dehydrated in a series of ethanol-water solution (30, 50, 70, and 90\% ethanol, $5 \mathrm{~min}$. each) and critical point dried under $\mathrm{CO}_{2}$ atmosphere for $20 \mathrm{~min}$. Mounting was done on aluminum stubs, and cells were coated with 90-J thick gold palladium coating in a polaron Sc 7640 sputter coater (VG Microtech, East Sussex, TN22, England) for $30 \mathrm{~min}$. Coated cells were viewed at $\mathrm{kV}$ with Scanning Electron Microscopy (FEI inspect S, Holland, HBRC). Dx 4 Prime Energy Dispersive Xray Spectrometer (EDX) was performed at different $\mathrm{kV}$ for confirmation of the $\mathrm{Fe}^{+2}$ accumulations in the yeast cells .

\section{Statistical analysis}

Statistical analysis of the obtained data was carried out for analysis of variance according to (Snedecor and Cochran. 1992) using computer Statistical programe MSTAT-C. Means were compared by the L.S.D. values at 5\% level.

\section{Results and Discussion}

The data in Fig. 1 and 2) revealed that all tested S. cerevisiae strains in alive form were more efficient for biosorption of $\mathrm{Fe}^{+2}$ than the dead form . The maximum adsorption efficiency $(95.34 \%) 21.9 \mathrm{mg} \mathrm{Fe} / \mathrm{g}$ yeast biomass was recorded by alive cells of $S$. cerevisiae F-707 followed by strains F-125, FC614, F-514, F-524 which recorded 17.9, 17.7, 17.0, 16.4,15.8 $\mathrm{mg} \mathrm{Fe}^{+2} / \mathrm{g}_{\text {biomass, }}$ respectively. So, the above five yeast strains in alive form were chosen according to their efficiencies in biosorption of $\mathrm{Fe}^{+2}$ for further studies. The data in Table 1 . revealed that yeast strains F- 707, FC- 614, F-514 in alive form showed the highest biosorption efficiency for $\mathrm{Fe}^{+2}$, as they could absorb $21.7,19.4,18.4 \mathrm{mg}$ $\mathrm{Fe}^{+2} / \mathrm{g}$ biomass respectively. $S$. cerevisiae in different forms has been studied for 
different purposes of research for example, living cell/dead cell (Kapoor and Viraraghavan, 1995), intact cell/ deactivated cell, immobilized cell/free cell (Veglio and Beolchini, 1997), raw material /pretreated cell by physicochemical process, wild type/mutant cell, and flocculent /non-flocculent cell. Marques $e t$ al. (1999) studied engineered /non-engineered cell, also, lab culture/waste industrial cell and cells from different industries (Park et al., 2003).

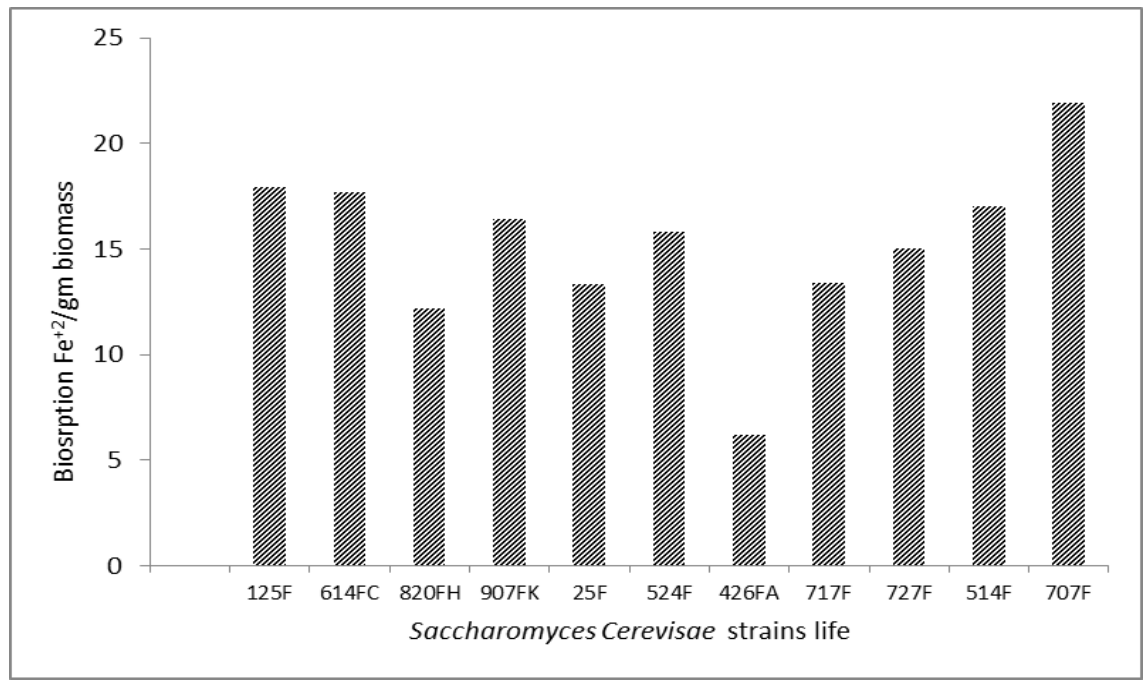

Fig. 1. Screening of some Saccharomyces cerevisiae strains for $\mathrm{Fe}^{+2}$ biosorption in alive form.

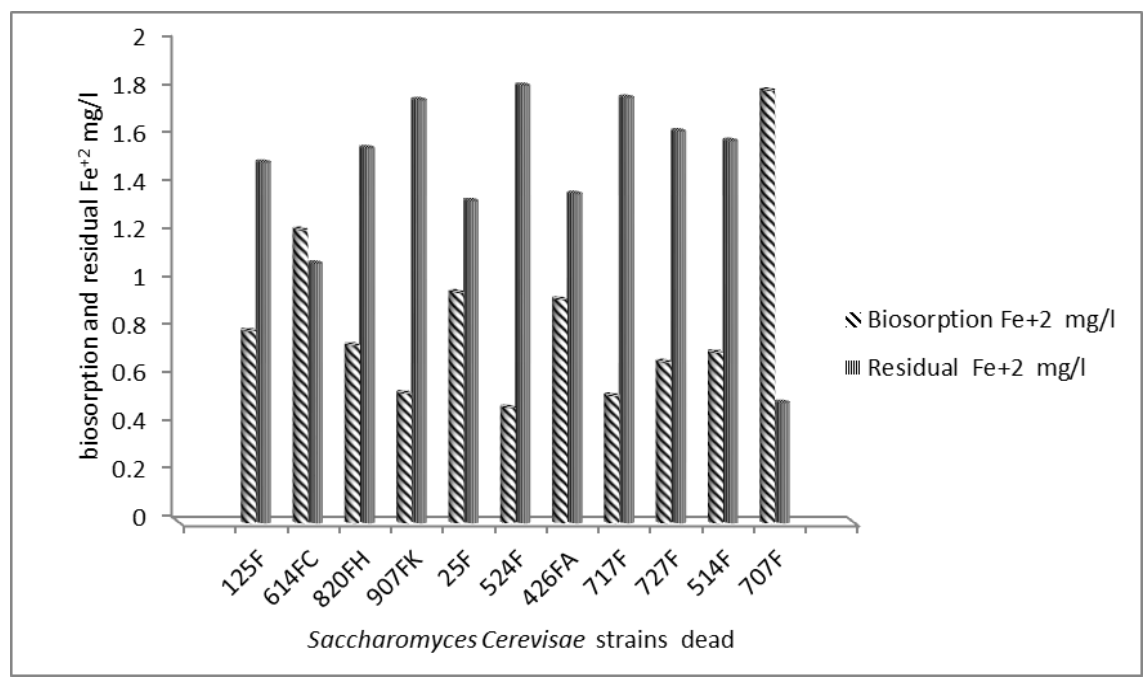

Fig. 2. Screening of some Saccharomyces cerevisiae strains for $\mathrm{Fe}^{+2}$ biosorption in dead form.

Egypt. J. Bot., Vol. 55, No. 2 (2015) 
TABLE 1. Screening of some selected Saccharomyces cerevisiae strains for $\mathrm{Fe}^{+2}$ biosorption after 90 min.

\begin{tabular}{|c|c|c|c|c|c|}
\hline Strain & $\begin{array}{l}\text { Biosorption } \\
\left.\mathrm{Fe}^{+2} \text { ( } \mathrm{mg} / \mathrm{l}\right)\end{array}$ & $\begin{array}{c}\text { Biosorption } \\
\text { efficiency } \\
(\%)\end{array}$ & $\begin{array}{c}\text { ResidualFe }_{(\mathrm{mg} / \mathrm{l})}^{+2} \\
\end{array}$ & $\begin{array}{l}\text { Residual } \\
\mathrm{Fe}^{+2}(\%)\end{array}$ & $\begin{array}{c}\text { Biosorption } \\
\mathrm{Fe}^{+2}(\mathbf{m g} \\
\mathrm{Fe}^{+2} / \mathrm{g} \\
\text { biomass }) \\
\end{array}$ \\
\hline 125 F-life & $1.76^{\mathrm{d}}$ & 80 & $0.54^{\mathrm{b}}$ & 20 & 17.6 \\
\hline 614 FC-life & $1.94^{\mathrm{b}}$ & 88.18 & $0.36^{\mathrm{d}}$ & 11.81 & 19.4 \\
\hline 907 FK-life & $1.14^{\mathrm{e}}$ & 51.81 & $1.16^{\mathrm{a}}$ & 24.09 & 11.4 \\
\hline 514 F-life & $1.84^{\mathrm{c}}$ & 83.63 & $0.46^{\mathrm{c}}$ & 16.36 & 18.4 \\
\hline 707 F-life & $2.17^{\mathrm{a}}$ & 98.63 & $0.13^{\mathrm{e}}$ & 1.36 & 21.7 \\
\hline
\end{tabular}

The different letters indicate significant difference at $\mathrm{P}>0.05$.

F, FC and FK means Saccharomyces cerevisae strains.

A number of references have proved that $S$. cerevisiae can remove toxic metals, recover precious metals and clean radionuclides from aqueous solutions to various extents. Schott and Gardner (1997) reported the recovery of light metals, such as aluminum by $S$. cerevisiae. Brady et al. (1994f) proved that the yeast cells of $S$. cerevisiae treated with hot alkali were capable of accumulating a wide range of heavy metal cations $\left(\mathrm{Fe}^{+3}, \mathrm{Cu}^{+2}, \mathrm{Cr}^{+3}, \mathrm{Hg}^{+2}, \mathrm{~Pb}^{+2}, \mathrm{Cd}^{+2}, \mathrm{Co}^{+2}, \mathrm{Ag}^{+}\right.$, $\mathrm{Ni}^{+2}$, and $\mathrm{Fe}^{+2}$. Heavy metals such as $\mathrm{Pb}, \mathrm{Au}, \mathrm{Co}, \mathrm{Cu}, \mathrm{Fe}$ and their respective cations can be completely removed from water and other aqueous environments by S.cerevisiae (Dhankhar et al., 2011, Simmons et al., 1995, Wang and Chen, 2006). Park et al. (2003) compared two strains of $S$. cerevisiae for the biosorption of cadmium. A yeast strain (ATCC834) which is used for the production of l-phenyl acetylcarbinol (IPAC) and another strain, ATCC24858 for ethanol production. They found that the thicker mannan layer and the larger specific surface layer seemed to benefit a larger cadmium uptake capacity for the strain S. cerevisiae ATCC834. Francisco et al. (2002) and Ksheminska et al. (2003) studied the diversity of $\mathrm{Cr}^{+6}$ resistant and $\mathrm{Cr}^{+6}$ sensitive bacteria to chromium in contaminated activated sludge. They reported that the mechanism of chromium resistance and reduction might differ in microbial community from group to group or from strain to strain within the same species.

As shown in Table 2. the equilibrium adsorption capacity increased as the contact time increased. The biosorption of $\mathrm{Fe}^{+2}$ by yeast biomass was rapid for first $20 \mathrm{~min}$. and equilibrium was nearly reached after $45 \mathrm{~min}$. Results revealed that the highest removal efficiency for $\mathrm{Fe}^{+2}$ by yeast biomass was occurred after 20 min. then the removal efficiency occurred slowly. This trend emphasizes that 
sorption times have an important effect on recovery efficiency, which decreases with increase biosorbent contact time with metal ions solution. Metal accumulation inside the cell may resulted from bioaccumulation, slow metabolic dependent removal mechanism, or by simple metal diffusion (Gaad, 1990).

TABLE 2. Screening of $707 \mathrm{~F}$ yeast strain for $\mathrm{Fe}^{+2}$ biosorption after different time intervals.

\begin{tabular}{|c|c|c|c|}
\hline $\begin{array}{c}\text { Time } \\
(\text { min. })\end{array}$ & $\begin{array}{c}\text { Biosorption } \\
\mathbf{F e}^{+2} \\
(\mathbf{~ m g} / \mathbf{l})\end{array}$ & $\begin{array}{c}\text { Residual } \\
\mathbf{F e}^{+2} \\
(\mathbf{~ m g} / \mathbf{l})\end{array}$ & $\begin{array}{c}\text { Biosorption } \mathbf{F e}^{+2}(\mathbf{m g} \\
\mathbf{F e}^{+2} / \mathbf{g} \\
\text { biomass })\end{array}$ \\
\hline 10 & $1.8^{\mathrm{b}}$ & $0.5^{\mathrm{a}}$ & 18 \\
\hline 20 & $2.16^{\mathrm{a}}$ & $0.14^{\mathrm{b}}$ & 21.6 \\
\hline 30 & $2.16^{\mathrm{a}}$ & $0.14^{\mathrm{b}}$ & 21.6 \\
\hline 45 & $2.16^{\mathrm{a}}$ & $0.14^{\mathrm{b}}$ & 21.6 \\
\hline 90 & $2.12^{\mathrm{ab}}$ & $0.18^{\mathrm{b}}$ & 21.2 \\
\hline 180 & $2^{\mathrm{ab}}$ & $0.3^{\mathrm{ab}}$ & 20 \\
\hline
\end{tabular}

The different letters indicate significant difference at $\mathrm{P}>0.05$.

Biosorption kinetics with an initial rapid metal uptake followed by slow uptake was observed, this kinetic model has been accepted for various biosorbents such as bacteria and fungi (yeast) under similar operation conditions (Tavares et al., 1995). In this connection Goyal et al. (2003) reported that the uptake of metal ions by microorganisms in batch systems has been shown to occur in two stages: an initial rapid stage (passive uptake), followed by much slower process (active uptake). The first stage is physical adsorption or ion exchange at the surface of the biomass, which is biosorption. The biosorption equilibrium occurs at the end of rapid physical adsorption stage (first-stage). Adsorption isotherm equation is frequently used to represent this equilibrium. The same behavior was observed by Han et al. (2006) for equilibrium time of $\mathrm{Zn}$ (II) and $\mathrm{Cu}$ (II).

Figures (3a, 3b, 3c and 3d) showed that removal efficiency increased with increasing the metal ions concentration. On the contrary biosiorption was decreased with increase dose of biomass. The best removal occured at $0.1 \mathrm{~g}$ yeast. This agrees with Cojocaru et al. (2009) who found that increase in density of the negative charge on the cell surface, causing proton removal from solution, thereby decreasing biosorption capacity of $\mathrm{Cu}$ (II) because of competitively adsorption of protons. A similar observation was reported by Ferraz and Teixeirain (1999) who suggested an increase of electrostatic interaction at high biomass concentration inhibited metal biosorption. When the biomass concentration is low, metal ions in the solution would not only be adsorbed to the surface of the biomass, but also enter into intracellular part through facilitating the concentration gradient of metal ions (Wang, 2002). It should be mentioned that the cadmium ions adsorption capacity decreased with increase of biosorbent dosage Vasudevan et al. (2002). Their theory is similar to that advanced by Zou et al. (2006) to account for the cell Egypt. J. Bot., Vol. 55, No. 2 (2015) 
surface remaining unsaturated at higher biosorbent dosage. Uslu and Tanyol (2006) found that the initial adsorption rates of $\mathrm{Cu}$ (II) decreased with increased biosorbent concentration.

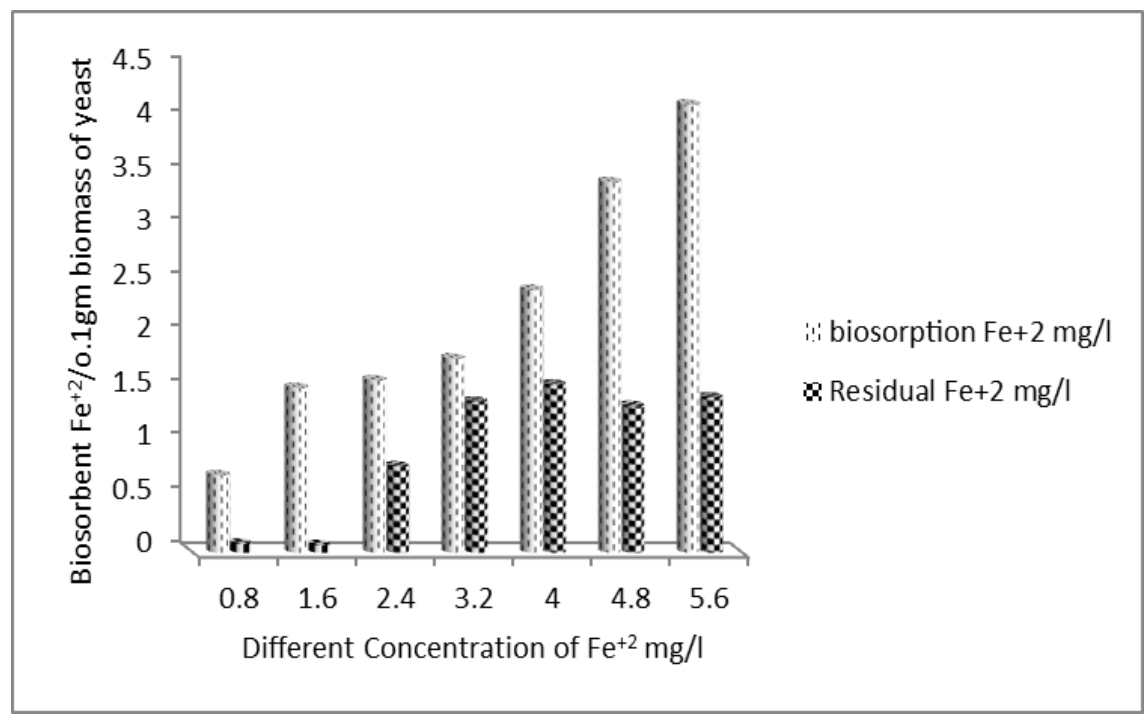

Fig. (3a). Estimation of the biosorbed and residual $\mathrm{Fe}^{+2}$ using different concentrations in the culture filtrates of strain 707F.

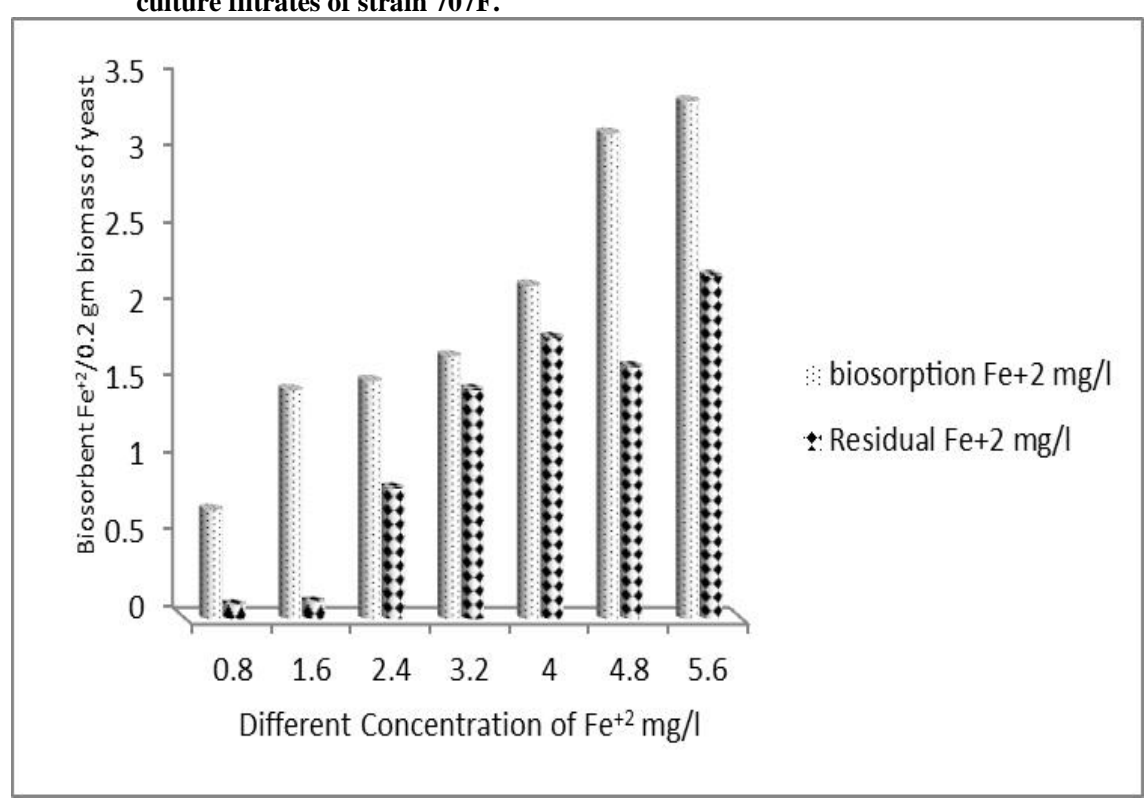

Fig. (3b). Estimation of the biosorbed and residual $\mathrm{Fe}^{+2}$ using different concentrations in the culture filtrates of strain 707F.

Egypt. J. Bot., Vol. 55, No. 2 (2015) 


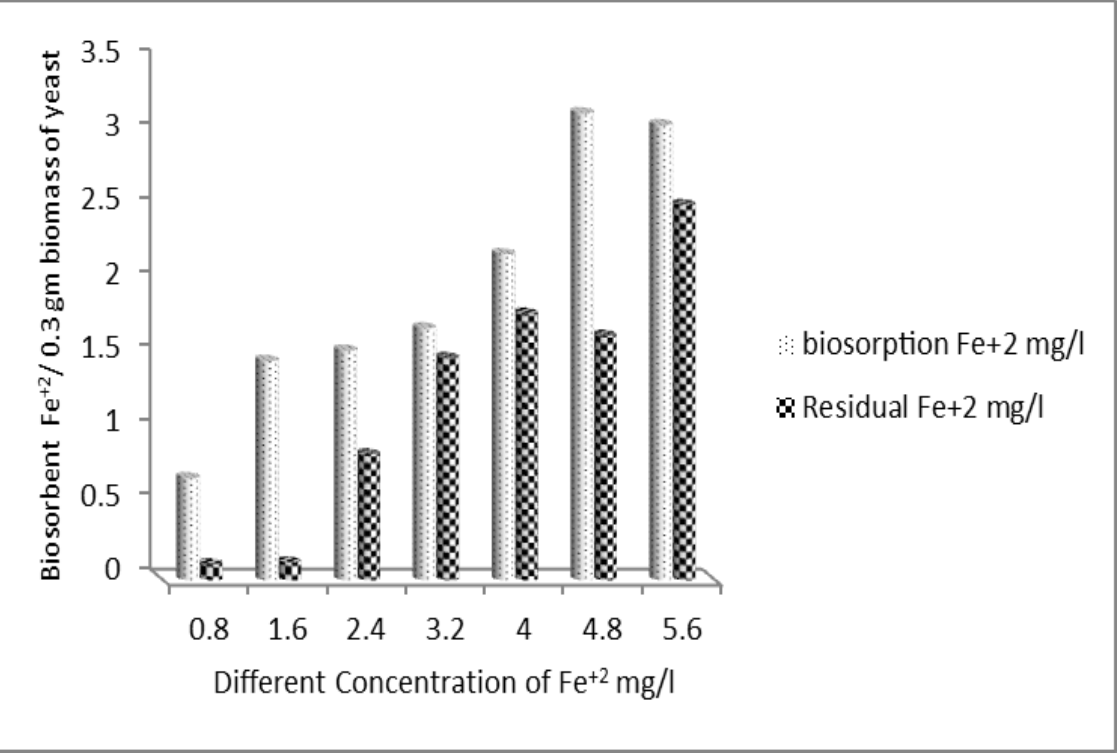

Fig. (3c). Estimation of the biosorbed and residual $\mathrm{Fe}^{+2}$ using different concentrations in the culture filtrates of strain $707 \mathrm{~F}$.

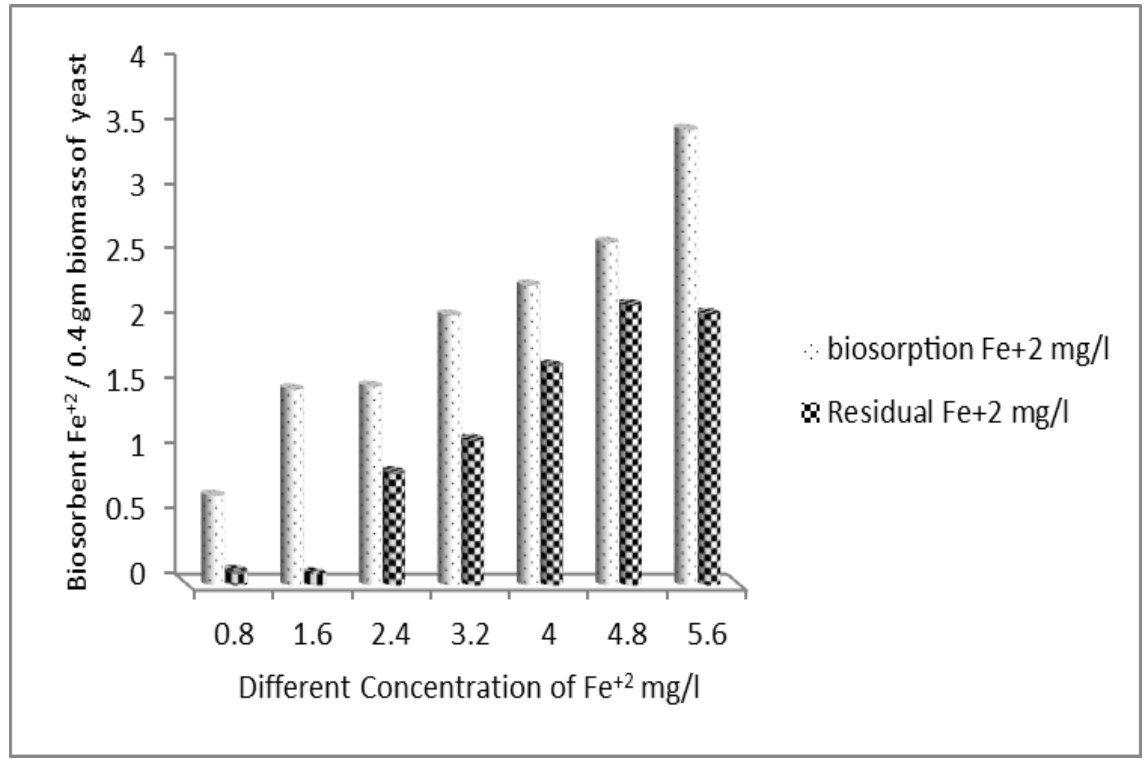

Fig. (3d). Estimation of the biosorbed and residual $\mathrm{Fe}^{+2}$ using different concentrations in the culture filtrates of strain $707 \mathrm{~F}$.

Egypt. J. Bot., Vol. 55, No. 2 (2015) 
The charge of the adsorbate and adsorbent often depends on the $\mathrm{pH}$. The adsorption $\mathrm{Fe}^{+2}$ as a function of $\mathrm{pH}$ were measured. As shown in Table 3. there were increases in biosorption uptake equilibrium with increasing $\mathrm{pH}$ from 4.5 to 9 for $\mathrm{Fe}^{+2}$ ions. Similar results were detected by Volesky (1990) who found that the optimal $\mathrm{pH}$ value is 5-9 for $\mathrm{Cu}$ (II) biosorption by $S$. cerevisiae. Also, Mapolelo and Torto (2004) proved that the optimal $\mathrm{pH}$ values are greater than 5 for $\mathrm{Cu}^{+2}$ and $\mathrm{Zn}^{+2}$. Generally, an increase of $\mathrm{pH}$ causes deprotonation of metal ions binding sites exposed by cellular surface. However, a decrease of $\mathrm{pH}$ causes competition between protons and positively charged metal ions. However these rules concern only cations. Since biosorption is reversible process, decreasing $\mathrm{pH}$ would result in deprotonation. This property is used in regeneration of biosorbents (Naja and Volesky, 2010).

TABLE 3. Effect of different pH values on $\mathrm{Fe}^{+2}$ uptake by strain $707 \mathrm{~F}$ after 20 min.

\begin{tabular}{|l|c|c|c|}
\hline \multicolumn{1}{|c|}{$\mathbf{p H}$} & $\begin{array}{c}\text { Biosorption } \\
\mathbf{F e}^{+2}(\mathbf{~ m g / l})\end{array}$ & $\begin{array}{c}\text { Residual } \\
\mathbf{F e}^{+2}(\mathbf{~ m g} / \mathbf{l})\end{array}$ & $\begin{array}{c}\text { Biosorption } \mathbf{F e}^{+2} \\
(\mathbf{m g ~ F e} \\
\mathbf{b i o m a s s}^{+2}\end{array}$ \\
\hline 4.5 & $5.21^{\mathrm{bc}}$ & $0.39^{\mathrm{cd}}$ & 52.1 \\
\hline 5 & $5.32^{\mathrm{ab}}$ & $0.28^{\mathrm{de}}$ & 53.2 \\
\hline 5.5 & $4.8^{\mathrm{e}}$ & $0.8^{\mathrm{a}}$ & 48 \\
\hline 6 & $5.06^{\mathrm{d}}$ & $0.54^{\mathrm{b}}$ & 50.6 \\
\hline 6.5 & $5.11^{\mathrm{cd}}$ & $0.49^{\mathrm{bc}}$ & 51.1 \\
\hline 7 & $5.35^{\mathrm{a}}$ & $0.25^{\mathrm{e}}$ & 53.5 \\
\hline 7.5 & $5.25^{\mathrm{ab}}$ & $0.35^{\mathrm{de}}$ & 52.5 \\
\hline 8 & $5.31^{\mathrm{ab}}$ & $0.29^{\mathrm{de}}$ & 53.1 \\
\hline 8.5 & $5.28^{\mathrm{ab}}$ & $0.32^{\mathrm{de}}$ & 52.8 \\
\hline 9 & $5.37^{\mathrm{ab}}$ & $0.23^{\mathrm{de}}$ & 53.7 \\
\hline
\end{tabular}

The different letters indicate significant difference at $\mathrm{P}>0.05$

Removal of $\mathrm{Fe}^{+2}$ increases with the agitation time as shown in Table 4. even until $150 \mathrm{rpm}$ the removal increases slightly but it is lower when the agitation speed increased to 200 and $250 \mathrm{rpm}$. Accumulation starts to predominate after some time of the Saccharomyces cerevisiae growth around $150 \mathrm{rpm}$ of agitation .These results agreement with Handan et al. (2002). Biosorption of chromium (VI) on to cone biomass of Pinus sylvestris was studied with variation in agitation speed. The biosorption of $\mathrm{Cr}(\mathrm{VI})$ was increased when the maximum chromium biosorption occurred at $150 \mathrm{rpm}$ agitation. 
TABLE 4. Effect of agitation rate on $\mathrm{Fe}^{+2}$ uptakes by strain $707 \mathrm{~F}$ after 20 min.

\begin{tabular}{|c|c|c|c|}
\hline Agitation rpm & $\begin{array}{c}\text { Biosorption } \\
\mathbf{F e}^{+2}(\mathbf{m g} / \mathbf{l})\end{array}$ & $\begin{array}{c}\text { Residual } \\
\mathbf{F e}^{+2}(\mathbf{m g} / \mathbf{l})\end{array}$ & $\begin{array}{c}\text { Biosorption } \mathbf{F e}^{+2} \\
\left(\mathbf{m g} \mathbf{F e}^{+2} \mathbf{g}\right. \\
\text { biomass })\end{array}$ \\
\hline 100 & $5.15^{\mathrm{b}}$ & $0.45^{\mathrm{c}}$ & 51.5 \\
\hline 150 & $5.24^{\mathrm{a}}$ & $0.36^{\mathrm{d}}$ & 52.4 \\
\hline 200 & $4.87^{\mathrm{d}}$ & $0.73^{\mathrm{a}}$ & 48.7 \\
\hline 250 & $4.99^{\mathrm{c}}$ & $0.61^{\mathrm{b}}$ & 49.9 \\
\hline
\end{tabular}

The different letters indicate significant difference at $\mathrm{P}>0.05$

Temperature has an influence on the biosorption of metal ions, but to a limited extent under a certain range of temperature, which indicates that ion exchange mechanism exists in biosorption to some extent . Biosorption process is usually not operated at high temperature because it will increase the operational cost (Wang, 2002). In our results the different temperature from $20^{\circ} \mathrm{C}$ to $40{ }^{\circ} \mathrm{C}$ proved that the optimal temperature values are greater and don't have more effect on biosorption of iron. Brady and Duncan (1994b) found that temperature $\left(5-40^{\circ} \mathrm{C}\right)$ had minor effect on the accumulation level of $\mathrm{Cu}^{+2}, \mathrm{Co}^{+2}$ or $\mathrm{Cd}^{+2}$ by free cells of S.cerevisiae in suspension. Adsorption reactions are normally exothermic ,so biosorption capacity increases with decrease of temperature (Kapoor andViraraghavan.1997) . In the range of $15^{\circ}-40^{\circ} \mathrm{C}$, the maximum equilibrium biosorption capacity for $\mathrm{Pb}(\mathrm{II}), \mathrm{Ni}(\mathrm{II})$ and $\mathrm{Cr}(\mathrm{VI})$ ions by the inactive S.cerevisiae was reached at temperature of $25^{\circ} \mathrm{C}$.The decrease in capacity at higher temperature between 25 and $40^{\circ} \mathrm{C}$ revealed that the processes of biosorption for these metal ions by $S$. cerevisiae are exothermic. The decrease of biosorption capacity at higher temperature may be due to the damage of active binding sites in the biomass (Özer and Özer ,2003).However, (Goyal et al ., 2003) found that the metal biosorption of $\mathrm{Cr}$ (VI) by S. cerevisiae increases with increasing temperature in the range of $25-45^{\circ} \mathrm{C}$, they Explained that higher temperature would lead to higher affinity of sites for metal or binding sites on the yeast. The energy of the system facilitates $\mathrm{Cr}(\mathrm{VI})$ attachment on the cell surface to some extent .When the temperature is too high, there is a decrease in metal sorption due to distortion of some sites of the cell surface available for metal biosorption (Table 5).

The SEM and EDX examination of $\mathrm{Fe}^{+2}$ biosorption by $707 \mathrm{~F}$ revealed the presence of $\mathrm{Fe}^{+2}$ as discrete particles attached or near cell surface of yeast. The EDX confirmed that $\mathrm{Fe}^{+2}$ was uniformly distributed and adsorbed to the cell surfaces as $707 \mathrm{~F}$. Electron microscopic observation carried out by Mullen et al. (1989) clarified the presence of $\mathrm{Ag}^{+2}$ as discrete particles at or near the cell wall of both Gram-positive and Gram-negative bacteria and the presence of silver was confirmed by energy dispersive X-ray analysis (EDX). Large particles containing gold were localized in Sargassum natans cells by EDX carried out in

Egypt. J. Bot., Vol. 55, No. 2 (2015) 
conjunction with scanning electron microscopy (Srivastava and Thakur, 2006). Leusch et al. (1995), using the X-ray photoelectron spectroscopy, observed that iron was present in two oxidation states when brown seaweed $S$. fluitans was exposed to $\mathrm{Fe}^{+2}$, while only $\mathrm{Fe}^{+3}$ was present when the biomass was exposed to ferric ions. SEM and EDX analysis of S.fluitans revealed that metal ions $\left(\mathrm{Cr}^{+6}\right)$ was uniformly distributed and adsorbed to the surface of the cells initially. Limin et al. (2009) mentioned that during sorption most of the lead was adsorbed on the surface of the cell. Lead adsorption by $S$. cerevisiae has mainly resulted from both ion exchange and the surface complexation as indicated by SEM-EDX analysis. Also studies revealed that chromium adsorption have marked effects on the fungal morphology. (Fig. 4a and 4b).

TABLE 5. Effect of different temperature on $\mathrm{Fe}^{+2}$ uptake by strain $707 \mathrm{~F}$ after 20 min.

\begin{tabular}{|c|c|c|c|}
\hline Temperature $^{\circ} \mathrm{C}$ & $\begin{array}{l}\text { Biosorption } \\
\mathrm{Fe}^{+2}(\mathrm{mg} / \mathrm{l})\end{array}$ & $\begin{array}{c}\text { Residual } \\
\mathrm{Fe}^{+2}(\mathrm{mg} / \mathrm{l})\end{array}$ & $\begin{array}{c}\text { Biosorption } \mathrm{Fe}^{+2} \\
(\mathrm{mg} \mathrm{Fe} \\
\text { biomass })\end{array}$ \\
\hline 20 & $5.29^{b}$ & $0.31^{\mathrm{b}}$ & 52.9 \\
\hline 25 & $5.08^{\mathrm{c}}$ & $0.52^{\mathrm{a}}$ & 50.8 \\
\hline 30 & $5.28^{\mathrm{a}}$ & $0.32^{\mathrm{c}}$ & 52.8 \\
\hline 35 & $5.35^{\mathrm{a}}$ & $0.25^{\mathrm{c}}$ & 53.5 \\
\hline 40 & $5.35^{\mathrm{a}}$ & $0.25^{\mathrm{c}}$ & 53.5 \\
\hline
\end{tabular}

The different letters indicate significant difference at $\mathrm{P}>0.05$

The similar letters insignificant at $\mathrm{P}>0.05$

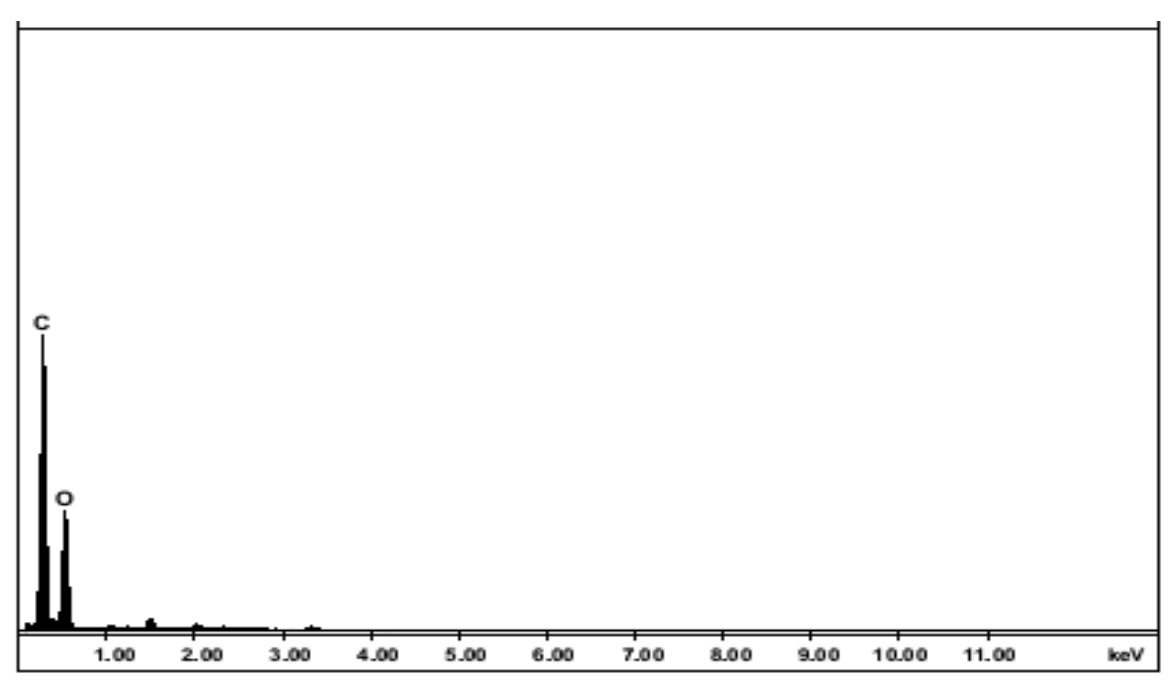

Fig. (4a) Energy dispersive x-ray (EDX) of the biosorbed $\mathrm{Fe}^{+2}$ by strain $707 \mathrm{~F}$ (control) by Scanning electron microscopy . 


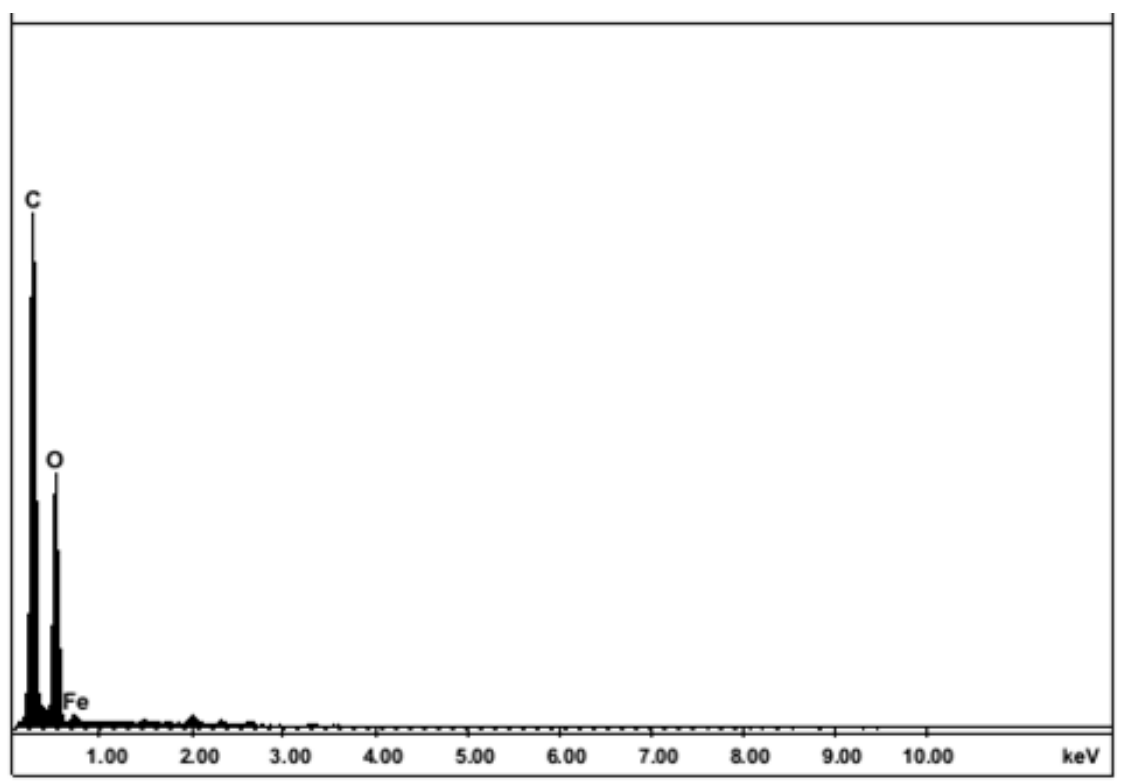

Fig. (4b) Energy dispersive $x$-ray (EDX) of biosorbed $\mathrm{Fe}^{+2}$ by strain $707 \mathrm{~F}$ cells treated with $5.6 \mathrm{mg} / \mathrm{l} \mathrm{Fe}^{+2}$ by Scanning electron microscopy.

\section{References}

Aksu, Z. (1998) Biosorption of heavy metals by microalgae in batch and continuous system. In: "Algae for Wastewater Treatment. Wong X-S, Tam, N.F.Y Germany. Springer-Verlag, 37-75. and CRC Press1576.

Brady, D. and Duncan, J.R. (1994b) Bioaccumulation of metal- cations by Saccharomy cescerevisiae. Appl.Microbiol.Biotechno, 141: 149-54.

Brady, D., Stoll, A. and Duncan, J.R. (1994f) Biosorption of heavy metal cations by non-viable yeast biomass. Environ.Technol, 15: 429-38.

Chojnacka, K. (2010) Biosorption and bioaccumulation -the prospects for practical applications, Environ. Int. 36: 299-307.

Cojocaru, C., Diaconu, M., Cretescu, I., Savic, J. and Vasic, V. (2009) Biosorptionof copper (II) ions from aqua solutions using dried yeast biomass Colloids and surfaces A Physicochemical and Engineering Aspects, 335: 181-188.

Das, B., Hazarika, P.I., Saikia, G.I., Kalita, H., Goswami, D.C. and Das, H.B. (2007) Removal of iron from groundwater by ash: A systematic study of a traditional method. J. Hazard Mater., 141 (3): 834-41.

Dhankhar, R., Hooda, A., Solanki, R. Sainger, P.A. (2111) Saccharomyces cerevisiae a potential biosorbent for biosorption of uranium, International Journal of Engineering Science and Technology, 3 (6): 5397-5407.

Egypt. J. Bot., Vol. 55, No. 2 (2015) 
Ferraz, A.I., and Teixeira, J.A. (1999) The use of flocculating brewer'syeast for Cr(III) and $\mathrm{Pb}$ (III) removal from residual wastewaters. Bioprocess, 21: 431-7.

Ferraz, A.I., Tavares, T. and Teixeira, J.A. (2004) C r (III) removal and recovery from Saccharomyces cerevisiae. Chem. Eng. J., 105: 11-20.

Francisco, R., Alpoim, M.C. and Morais, P.V. (2002) Diversity of chromium resistant and reducing bacteria in a chromium- contaminated activated sludge. J. Appl. Microbiol, 92, 837-843.

Gaad, G.M. (1990) Fungi and yeast for metal accumulation, in microbial mineral recovery, In: "Environmental Biotechnology", H.L. Lehrlich, C.L. Brierley (Ed.), McGraw-Hill, pp. 249-275.

Goyal, N., Jain, S.C. and Banerjee, U.C. (2003) Comparative studies on the microbial Adsorption of heavy metals. Adv. Environ. Res., 7: 311-9.

Han, R., Zhang, J., Zou, W., Xiao, H., Shi, J. and Liu, H. (2006) Biosorption of copper (II) and lead (II) from aqueous solution by chan in a fixed - bed column. J. Hazard. Mater., 133 (1-3): 262-268.

Handan, U, Kemal, B.y., yusuf, K. and Avni, C (2002) Biosorption of chromium(VI) and $\mathrm{Cr}(\mathrm{VI})$ ions on to S.cerevisiae:Determination of biosorption from aqueous solution by cone biomass of Pinus sylvestris heat, J. Hazard Mater B., 100: 219-29.

Kadukova ,J.and Vircikova,E.(2005) Comparison of differences between copper bioaccumulation and biosorption. Environmental International., 31: 227-232.

Kapoor, A., and Viraraghavan, T. (1995) Fungal biosorption . an alternative treatment option for heavy metal bearing wastewaters. Bioresource Technology, 53 , 195-206.

Kapoor, A. and Viraraghavan, T. (1997) Fungi as biosorption .In : "Biosorbents for Metal Ions". Wase D.A.J., Forster C.F., ed. London, UK: Taylor \& Francis; p.67-85.

Ksheminska, H., Jaglarz, A., Fedorovych, D., Babyak, L., Yanovych, D., Kaszycki, p. and Koloczeke, H. (2003) Bioremediation of chromium by the yeast Pichia guilliermondii: Toxicity and accumulation of $\mathrm{Cr}$ (III) and $\mathrm{Cr}$ (VI) and the influence of riboflavin on Cr tolerance. Microbiol . Res., 158, 59 - 67.

Leusch, A., Holan, Z.R. and Volesky, B. (1995) Biosorption of heavy metals $(\mathrm{Cd}, \mathrm{Cu}$, $\mathrm{Ni}, \mathrm{Pb} ; \mathrm{Zn})$ by chemically reinforced biomass of marine algae. J. Chemi. Technol Biotechnol., 62: 279-288.

Limin, D., Juan, D., Xin, B., Naili, Y., Chunhui, F. and Ying, Z. (2009) Mechanism of $\mathrm{Pb}$ (II) Biosorption by Saccharomyces cerevisiae, International Conference on Environmental Science and Information Application Technology, Wuhan, China. ESIAT, 1: 712-715.

Mapolelo, M. and Torto, N. (2004) Trace enrichment of metal ions in aquatic environments by Saccharomyces cerevisiae. Talanta., 64: 39-47. 
Marques, P.A., Pinheiro, H.M., Teixeira, J.A. and Rosa, M.F. (1999) Removal efficiency of $\mathrm{Cu}^{+2}, \mathrm{Cd}^{+2}$ and $\mathrm{Pb}^{+2}$ by waste brewery biomass: $\mathrm{pH}$ and cation association effects. Desalination, 124:137-44.

Mullen, L.D., Wolfe, D.C., Ferris, F.G., Beveridge, T.J., Flemming C.A. and Bailey, G.W. (1989) Bacterial sorption of heavy metal. Applied Environmental Microbiology, 55: $3143-3149$.

Naja, G. M. and Volesky, B. (2010) Treatment of Metal-Bearing Effluents: Removal and Recovery .In: "Handbook on Heavy Metals in the Environment". Wang L.K., Chen J.P., Hung Y.T., Shammas N.K., Ed. Boca Raton, F.L.: Taylor \& Francis.

Özer, A. and Özer, D. (2003) Comparative study of the biosorption of $\mathrm{Pb}$ (II), $\mathrm{Ni}$ (II) And $\mathrm{Cr}$ (VI) ions on to S.cerevisiae determination of biosorption heats . J. Hazard Mater B., 100: 219-29.

Paravathi, K. and Nagendran, R. (2008) Functional groups on waste beer yeast involved in chromium biosorption from electroplating effluent. World J. Microbio. Biotechnol., 24: 2865-2870.

Park, J.K., Lee, J.W. and Jung, J.Y. (2003) Cadmium uptake capacity of two strains of Saccharomyces cerevisiae cells. Enzyme., Microb. Technol, 33: 371-8.

Schott, E.J. and Gardner, R.C. (1997) Aluminum-sensitive mutants of Saccharomyces .Mol Gen Genet, 254: 63-72.

Sharma, S.K. (2001) "Adsorptive iron Removal From Groundwater". Lisse, The Netherlands : Swets \& Zeitlinger B.V.

Simmons, P., Tobin, J.M., and Singleton. I, (1995) Considerations on the use of commercially available yeast biomass for the treatment of metal containing effluents, Journal of Industrial Microbiology, 14 (3-4):240-246.

Snedecor, G.W. and W.G. Cochran. (1992) "Statistical Methods". $8^{\text {th }}$ ed. Iowa State Univ., Press, Ames. Iowa, USA.

Srivastava, S. and Thakur, I.S. (2006) Isolation and process parameter optimization of Aspergillus sp. for removal of chromium from tannery effluent. Biores. Technol., 97: $1167-1173$.

Tavares, M.T., Martins, C. and Neto, P. (1995) Biotreatment of $\mathrm{Cr}$ (VI) effluents., in: (Ed.) "Hazardous and industrial Wastes", A.K. Sengupta Technomics Publishing Co. pp. 223-232.

Uslu, G. and Tanyol, M. (2006) Equilibrium and thermo dynamic parameters of single and binary mixture biosorption of lead (II) and copper (II) ions.

Vasudevan, P., Padmavathy, V. and Dhingra, S.C. (2002) Biosorption of monovalent and divalent ions on baker's yeast. Bioresour.Technol., 82: 285-289.

Veglio, F. and Beolchini, F. (1997) Removal of metals by biosorption: A review. Hydrometallurgy, 44: 301-16.

Egypt. J. Bot., Vol. 55, No. 2 (2015) 
Volesky, B. (1990) Biosorption and biosorbents. "Biosorption of Heavy Metals". Florida: CRC press; p.3-5.

Wang, J.L. (2002) Immobilization techniques for biocatalysts and water, Bioresource Technology, 85: 155-158

Wang, J., and Chen, C. (2006) Biosorption of heavy metals by Saccharomyces cerevisiae: A review, Biotechnology Advances , 24 (5): 427-45.

Zou, W.H., Han, R.P., Chen, Z.Z., Shi, J. and Liu, H.M. (2006) Characterization and properties of manganese oxide coated zeolite (MOCZ) as adsorbent for removal of copper (II) and lead (II (ions from solution. J. Chem. Eng. Data., 51: 534-541.

(Received 24/11/ 2014; accepted 8 /1 / 2015 )

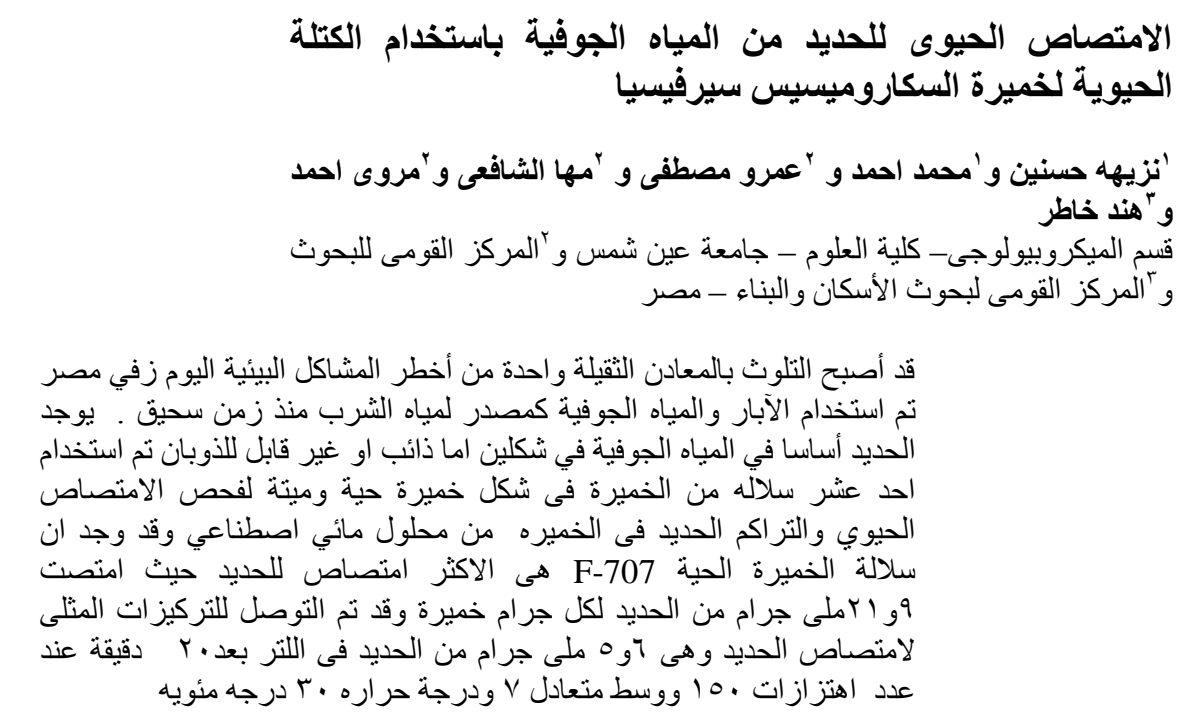

Egypt. J. Bot., Vol. 55, No. 2 (2015) 